Chirurgia (2019) 114: 639-649

No. 5, September - October

Copyright $@$ Celsius

http://dx.doi.org/10.21614/chirurgia.114.5.639

\title{
The Pancreatic Endocrine Tumors - Experience of First Surgical Clinic lasi
}

\author{
Eugen Târcoveanu, Cristian Lupascu, Alin Vasilescu, Radu Moldovanu, Dan Andronic, Delia Ciobanu, Costel Bradea
}

„I. Tănăsescu - VI. Buțureanu” First Surgical Clinic,"St Spiridon” University Hospital

"Gr.T. Popa" University of Medicine and Pharmacy lasi, Romania

Corresponding author:

Alin Vasilescu MD, PhD

First Surgical Clinic

"St Spiridon" University Hospital

Independentei str., no. 1, 700111

lasi, Romania

E-mail: vasilescu.alin@gmail.com

\section{Abbreviations:}

PNETS - Pancreatic Neuroendocrine Tumors;

GEP-NETS - Gastroenteropancreatic Neuro-Endocrine Tumors;

Ki 67 index - Immunohistochemical Criteria;

PNETS - Pancreatic NETs;

ZES - Zollinger Ellison Syndrome.

Received: 05.09.2019

Accepted: 14.10.2019

\section{Rezumat}

Tumorile pancreatice endocrine - experiența Clinicii 1 Chirurgie Iași

Tumorile neuroendocrine pancreatice (PNET-uri) sunt tumori rare, cu semne clinice variabile şi management chirurgical adesea provocator.

Metode: Am efectuat un studiu retrospectiv în Clinica 1 Chirurgie, Spitalul Universitar Sf. Spiridon, în ultimii 17 ani, care a inclus toți pacienții diagnosticați imunohistochimic cu tumori endocrine pancreatice, 61 tumori endocrine digestive (GINET and PNET). Rezultate: Au fost 26 de cazuri diagnosticate cu PNET. Proporția bărbați / femei a fost de 7/19, iar vârsta medie a fost de 41,93 2,48 ani (între 20 şi 79 de ani). 13 insulinoame, 5 gastrinoame, 2 gastrinoame asociate $\mathrm{cu}$ alte neoplazii endocrine (sindrom Wermer), 5 tumori pancreatice non-functionale şi 1 caz de ACTH-oma. Diagnosticul a fost sugerat de triada Whipple, în insulinoame, de sindromul Zollinger Ellison în gastrinoame şi sindrom Cushing în ACTHoame. Diagnosticul biologic a inclus markeri biologici (insulină, gastrină, cortizol). Diagnosticul topografic şi dimensiunii tumorii au fost appreciate prin examen cu ultrasunete, CT-scan, angiografie, PET-scan, Octreoscan şi ultrasonografie intraoperatorie. Procedurile chirurgicale pentru insulinoamele au fost: rezecția tumorii - 6 cazuri; splenopancreatectomii stângi - 3 cazuri; pancreatectomii stângi cu conservarea splinei - 2 cazuri; duodenopancreatectomii cefalice - 2 cazuri. De asemenea, prezentăm 5 cazuri de gastrinom $\mathrm{cu}$ ulcerații multiple şi intervenții chirurgicale multiple pentru hemoragie şi perforație cu peritonită. Cei doi pacienți cu sindrom Wermer au avut, de asemenea, ulcere 
complicate cu hemoragie şi peritonită şi adenom paratiroidian. Am tratat 5 tumori endocrine pancreatice nonfunctionale situate în coada pancreasului în 3 cazuri (splenopancreatectomie şi pancreatectomie stângă cu conservarea splinei) şi în capul pancreatic în 2 cazuri (duodenopancreatectomie cefalică şi o operație tip Beger).

Concluzii: Este necesară recunoaşterea semnelor clinice ale tumorilor secretante şi explorarea pacienților cu PNET. Imunohistochimia este obligatorie pentru confirmare, aprecierea proliferării şi a comportamentului biologic al tumorii şi permite utilizarea unei terapii specifice. Tratamentul chirurgical agresiv este indicat, chiar şi în stadii avansate.

Cuvinte cheie: tumorile endocrine pancreatice, insulinom, gastrinom, sindromul Zollinger-Ellison, sindromul Wermer, pancreatectomie

\begin{abstract}
Pancreatic neuroendocrine tumors (PNETs) are rare and characterized by widely variable clinical presentation and often challenging surgical management.

Methods: Retrospective study conducted during the last 15 years at the First Surgical Clinic of the Iasi „St Spiridon” University Hospital, and which included all the patients diagnosed with pancreatic endocrine tumors by immunohistochemistry.

Results: There were 26 cases diagnosed with PNET. The male/female ratios was 7/19 and mean age $41.93 \pm 2.48$ years (range 20-79 years). Of the PNET cases 13 were insulinomas, 5 gastrinomas, 2 gastrinomas associated with other endocrine neoplasms (Wermer syndrome), 5 non-functional endocrine pancreatic tumors and 1 ACTHoma. Clinical manifestations depended on tumor type: hypoglycemia and Whipple triad for insulinoma, Zollinger Ellison syndrome and complicated peptic ulcer (hemorrhage, perforation) for gastrinoma, Cushing syndrome for ACTHoma. Biological diagnosis included biological markers (e.g. insulin, gastrin and cortisol). Tumor site and size at diagnosis were determined by ultrasound, CT-scan, angiography, PETscan, octreoscan and intraoperative ultrasound. Surgical procedures for PNET insulinomas were: tumor resection - 6 cases; left splenopancreatectomy - 3 cases; left spleen-preserving pancreatectomy - 2 cases; pancreaticoduodenectomy - 2 cases. We also present 4 cases of gastrinoma with multiple ulcers and multiple surgical interventions for hemorrhage and perforation with peritonitis. The two patients with Wermer syndrome also had ulcers complicated with hemorrhage and peritonitis and parathyroid adenoma. Nonfunctional pancreatic endocrine tumors were diagnosed in 5 women of which in 3 the tumors were located in the pancreatic tail (in which splenopancreatectomy and left pancreatectomy with spleen preservation were performed) and in 2 in the pancreatic head (in which pancreaticoduodenectomy and Beger type operation were performed).

Conclusions: Knowledge of clinical signs of secreting tumors and exploring the patients are of crucial importance for management of PNETs. Immunohistochemistry is mandatory for confirming the diagnosis and assessing the proliferation and biological behavior of the tumor, thus facilitating the administration of specific therapy. Aggressive surgical treatment is indicated, even in advanced stages.
\end{abstract}

Key words: pancreatic endocrine tumors, insulinoma, gastrinoma, Zollinger-Ellison syndrome, Wermer syndrome, pancreatectomy 


\section{Introduction}

Pancreatic neuroendocrine tumors (PNETs) are part of the gastroenteropancreatic neuroendocrine tumors (GEP-NETs), a heterogeneous group of tumors originating from neuroendocrine cells that can occur throughout the digestive tract (1).

In 2010 WHO introduced the term neuroendocrine and simplified the classification of these tumors by using histological (number of mitoses/10 HPF) and immunohistochemical criteria (Ki 67 index) (2).

Most NETs are GEP-NETs - over 90\%. Of these, the most common are small bowel NETs (43\%), colorectal NETs (27\%) and pancreatic NETs (PNETs) - 28\% $(3,4)$. In recent years the overall incidence of PNETs is an increase, probably due to the advances in diagnosis (imaging, immunohistochemistry, genetics, and molecular biology).

Non-functional PNETs represent $15-70 \%$ of all neuroendocrine tumors of the pancreas. Insulinoma and gastrinoma are the most common functional PNETs and the sporadic forms are more common than those occurring in MEN syndromes. With the exception of gastrinoma, almost all tumors have a slightly higher incidence in women. PNETs occur in patients aged 30-60 years (3).

\section{Methods}

This retrospective study was done at The First Surgical Unit of the Iaşi "Sf. Spiridon" University hospital between 2001 and 2018. Clinical, laboratory, intraoperative and histopathological data were included in a MS Access Office XP database.

Included in the study were only the patients operated for digestive endocrine tumors diagnosed histopathologically and confirmed immunohistochemically.

A multidisciplinary team evaluated each patient in order to determine the likely origin, malignant vs benign morphological characteristics, and chances for a successful surgical approach.

\section{Results and Discussions}

During the study interval 61 patients diagnosed with digestive endocrine tumors have been treated, of which 26 PNETs and 35 GI-NETs (stomach - 5 cases, duodenum - 1 case, small bowel - 10 cases, appendix - 9 cases, colorectal 6 cases, liver metastasis - 4 cases, of which 3 cases with primary GI-NET tumors operated in another surgical clinic).

Male/female ratio was 19/42 (30\%/70\%) with no difference between PNET compared to GI-NET. Mean overall age was $41.93 \pm 2.48$ years (range 20-68 years): mean age in PNET group was $41.90 \pm 3.095$ years (range 27-68 years) and in GINET group $42 \pm 4.365$ years (range 20-79 years).

Next we will refer only to PNET. We treated the following PNET types: insulinoma - 13 cases, gastrinoma - 7 cases, nonfunctional PNET - 5 cases, ACTHoma - 1 case.

Most cases were recorded in women. Male/ female ratio was: insulinoma - 3/10, gastrinoma - 2/5, nonfunctional PET - 1/4, ACTHoma - 0/1. In order of frequency a literature review of the PNETs described so far are: insulinomas (70\% of PNETs), gastrinomas (Zollinger-Ellison syndrome, 20\%), VIPomas (Verner-Morrison syndrome, 3\%), glucagonomas (1\%), the other tumors accounting less than $1 \%$ (somatostatinoma, ACTHoma, GRFoma, serotoninoma, PPoma, PNET secreting calcitonin, renin, luteinizing hormone, neurotensin, ghrelin, cholecystokinin, erythropoietin, insulin-like growth factor-2) and non-secreting pancreatic endocrine tumors $-30 \%$ (5).

Clinical manifestations depended on the tumor type: hypoglycemia and Whipple triad for insulinoma, Zollinger Ellison Syndrome and complicated peptic ulcer (hemorrhage, perforation) for gastrinoma, Cushing syndrome for ACTHoma.

Biological diagnosis included the following biological markers: insulin, gastrin, and cortisol. Tumor site and size were determined by ultrasound, CT-scan, angiography, PET-scan (1 case), octreoscan (1 case). Histopathological and immunohistochemical diagnosis were made in all cases. Tumor sizes were: for 
Table 1. Tumor site of PNETs

\begin{tabular}{lrr}
\hline PNETs & \multicolumn{2}{c}{ Tumor site } \\
\hline & $\begin{array}{r}\text { pancreatic head } \\
\text { \& istmus }\end{array}$ & $\begin{array}{r}\text { pancreatic body } \\
\text { \& tail }\end{array}$ \\
\hline Insulinoma & $33.3 \%$ & $66.6 \%$ \\
\hline Gastrinoma & $16.7 \%$ & $83.3 \%$ \\
\hline Nonfunctional PNET & $60 \%$ & $40 \%$ \\
\hline ACTHoma & 0 & $100 \%$ \\
\hline
\end{tabular}

insulinoma $-2.75 \pm 0.21 / 1.5-4 \mathrm{~cm}$, for gastrinoma $-1.75 \pm 0.75 / 1-2.5 \mathrm{~cm}$, ACTHoma -2.5 $\mathrm{cm}$, nonfunctional PNET $-5.12 \pm 0.96 / 3-7$ $\mathrm{cm}$ (ANOVA test; $\mathrm{p}=0.010$ ). PNETs were predominantly located in the body and tail of the pancreas (Table 1).

Multiple endocrine neoplasia type 1 (MEN 1) was diagnosed in 4 cases (3 cases associated with gastrinoma and 1 case associated with insulinoma. In another case not included in this series PNET was associated with extraadrenal pheochromocytoma and ovarian cyst.

\section{PNET - insulinoma}

PNET - insulinoma is produced by the proliferation of pancreatic beta cells, characterized by insulin hypersecretion independent of the blood glucose regulation system. Diagnosis was made based on: the classic clinical triad known as "Whipple triad" - symptoms and signs of hypoglycemia, blood glucose level below $50 \mathrm{mg} / \mathrm{dL}(2.7 \mathrm{mmol} / \mathrm{L})$, and relief of symptoms after glucose administration and high insulin levels; ultrasound (Fig. 1) and
CT-scan (Fig. 2, 3) were performed in all cases. Various brain injuries due to severe hypoglycemia were recorded in 9 cases. Diagnosis was delayed in 8 cases due to neuropsihiatric symptoms.

The following surgical procedures were performed: tumor resection $41.66 \%$ (6 cases); (Fig. 4), left splenopancreatectomy 25\% (3 cases); spleen-preserving left pancreatectomy $16.66 \%$ ( 2 cases), pancreaticoduodenectomy 16.66\% (2 cases) (Fig. 5) and in one case (MEN I) tumor resection was associated with resection of a parathyroid adenoma.

The diagnosis was made by classical histopathological examination, special stains (Fig. 6), electron microscopy in 3 cases, reveals pleomorphic granules, surrounded by a clear halo - typical appearance of insulin storage in beta cells (we detected in the same tumor gastrin secretory cells) (Fig. 7) and confirmed by immunohistochemistry (Fig. 8-10).

Postoperative complications after tumor resection were pancreatic fistula (2 cases) and pancreatic pseudocyst (1 case) and after pancreaticoduodenectomies delayed gastric emptying in one case.

About $10 \%$ of insulinomas are multiple and about 5\% are associated with MEN 1 (6-8) (one case in our series $-3,84 \%)$. In our case with MEN: a 28-year-old woman who neuropsihiatric symptoms was admitted with clinical and biological manifestations of insulinoma and hyperparathyroidism. Abdominal CT scan and Cervical ultrasound revealed pancreatic tumor and parathyroid adenoma. Pancreatic

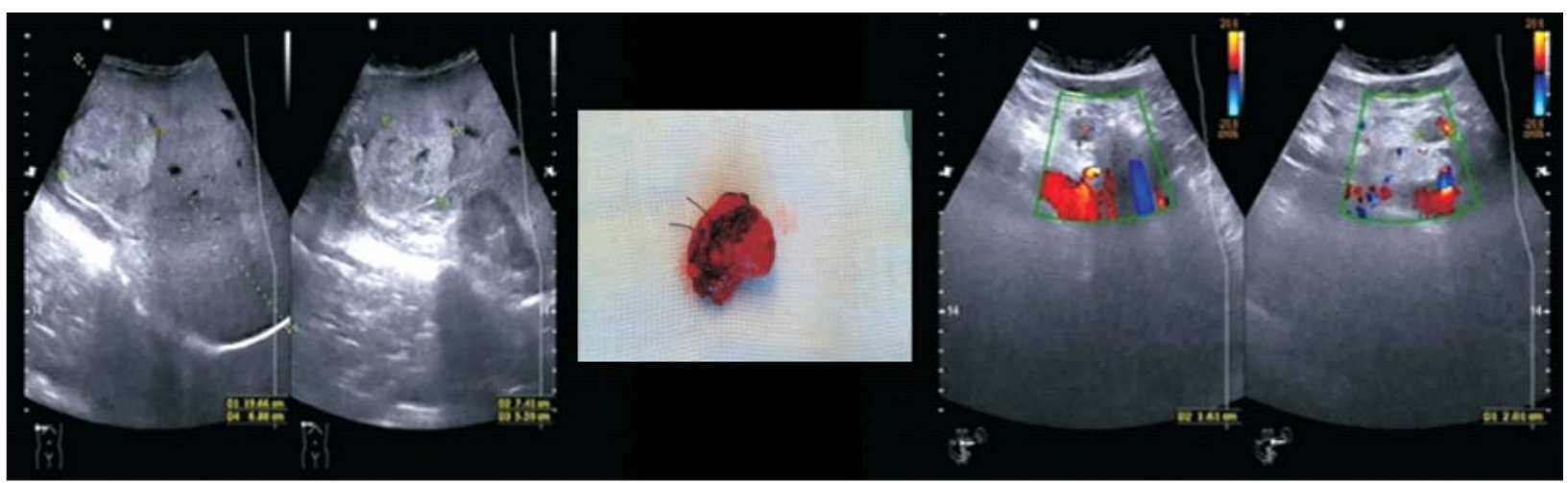

Figure 1. Ultrasound exam insulinoma: tumor in the pancreatic body - tumor resection 


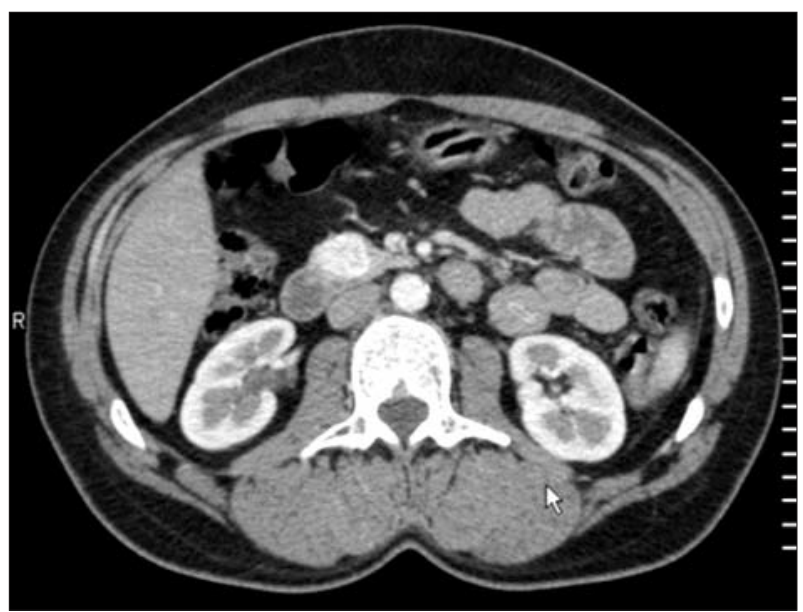

Figure 2. CT, 41-year-old female, insulinoma of the pancreatic head

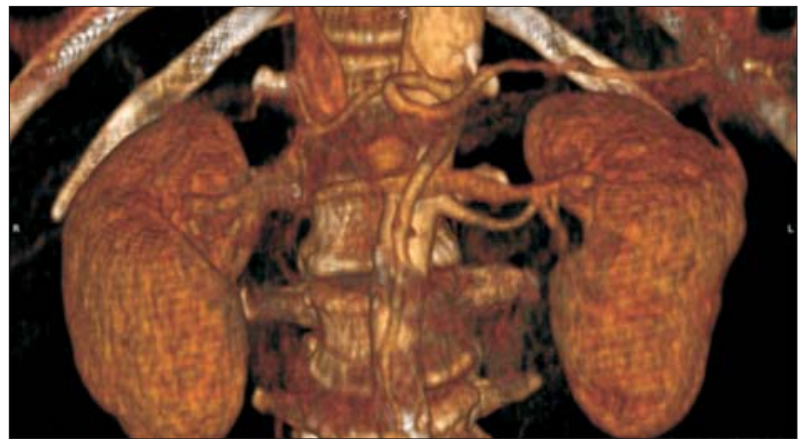

Figure 3. Abdominal CT images reconstructed: 67-year-old female, insulinoma of the pancreatic body

tumor enucleation and ablation of the parathyroid adenoma by Koher cervicotomy were performed, the postoperative course

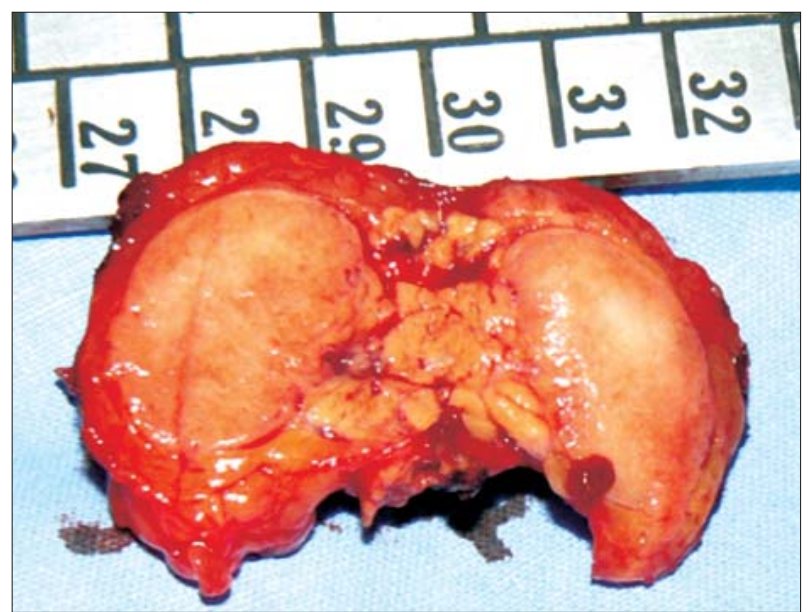

Figure 4. Surgical specimen - pancreatic insulinoma enucleated tumor encapsulated

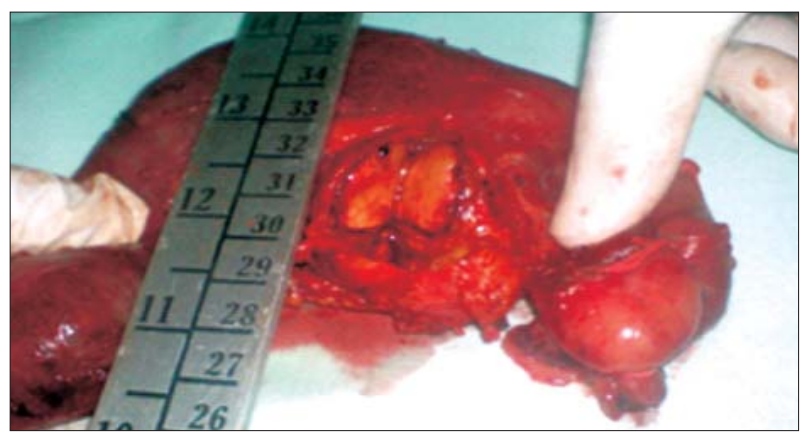

Figure 5. Surgical specimen - pancreaticoduodenectomy for insulinoma being uneventful (Fig. 11). Histopathological examination made the diagnosis of parathyroid adenoma, confirmed by immunohisto-
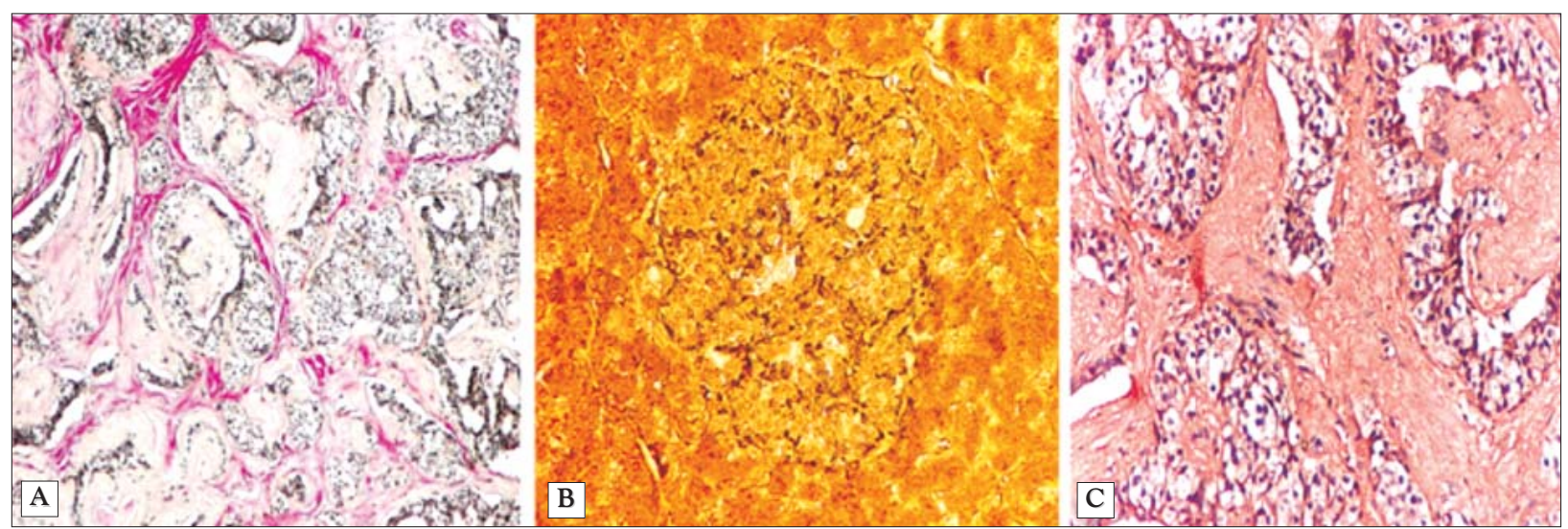

Figure 6. Microscopy of pancreatic endocrine tumor: (A) endocrine tumor with light cells with oxyphil cytoplasma and amyloid stroma, van Gieson staining; (B) endocrine argyrophilic tumor, Grimelius staining; (C) endocrine tumor with amyloid stroma, Congo red staining 

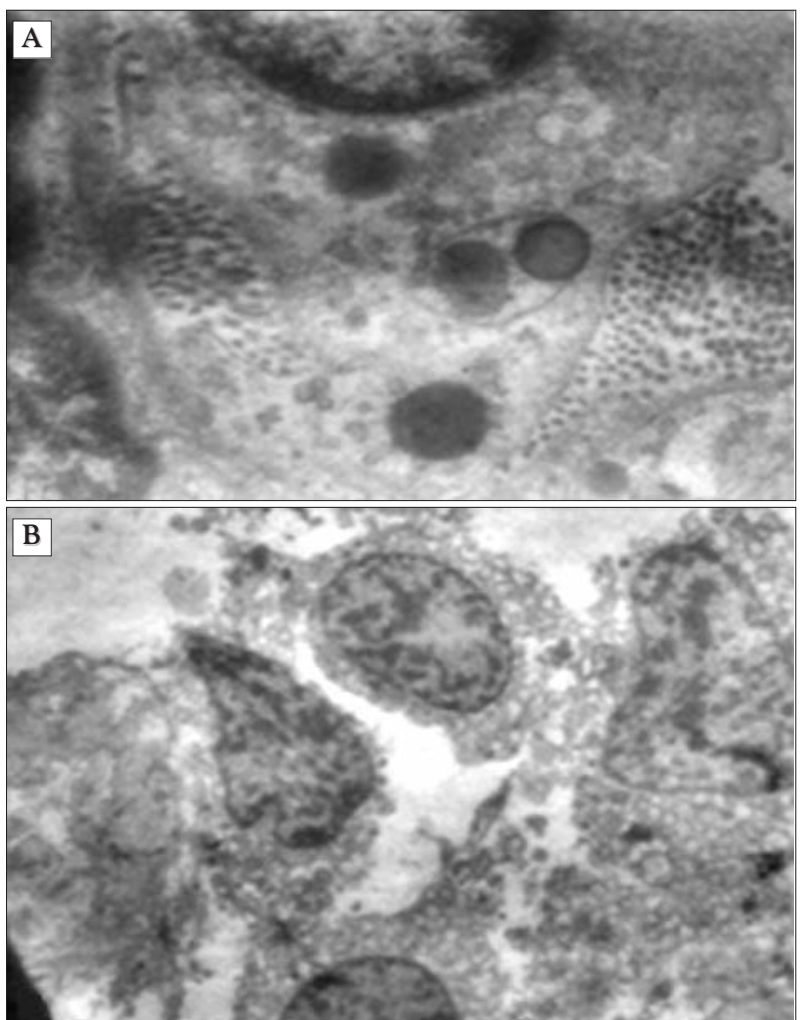

Figure 7. Endocrine pancreatic tumour, pancreatic insulinoma - in the same tumor two types of endocrine cells coexist, of which only one is clinically manifest:

(A) insulin-secreting cells (B cells) 6500x;

(B) Gastrin-secreting cells (oxyphillic cells), 1100x.

chemistry. Immunohistochemically, insulinomas express markers common to all neuroendocrine tumors. In addition they are positive for antiinsulin monoclonal antibodies. Like in literature, there is no correlation between the severity of clinical presentation and the size or malignant potential of insulinoma (9-11).

\section{PNET - gastrinoma}

The diagnosis of PNET - gastrinoma was based on Zollinger Ellison syndrome (ZES) is characterized by triad: gastric acid hypersecretion, jejunal peptic ulcer and PNET (12, 13). In our series, the patients were presented with multiple complicated peptic ulcers and high gastrin levels: ultrasound and CT-scan identified the pancreatic tumor. For diagnosis very usefull are: endoscopic ultrasound with a sensitivity of $46 \%$ for duodenal gastrinomas, $75 \%$ for tumors with pancreatic localization

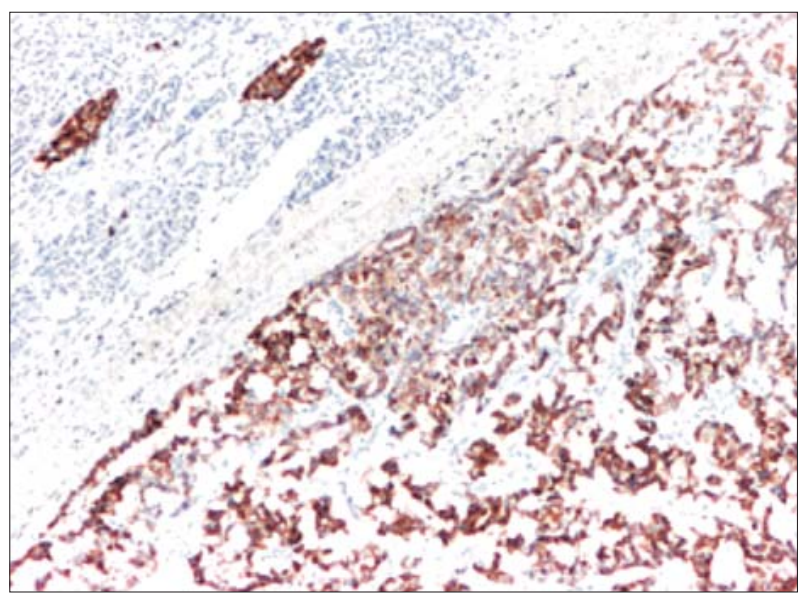

Figure 8. Immunohistochemistry of pancreatic endocrine tumor: intensely positive chromogranin

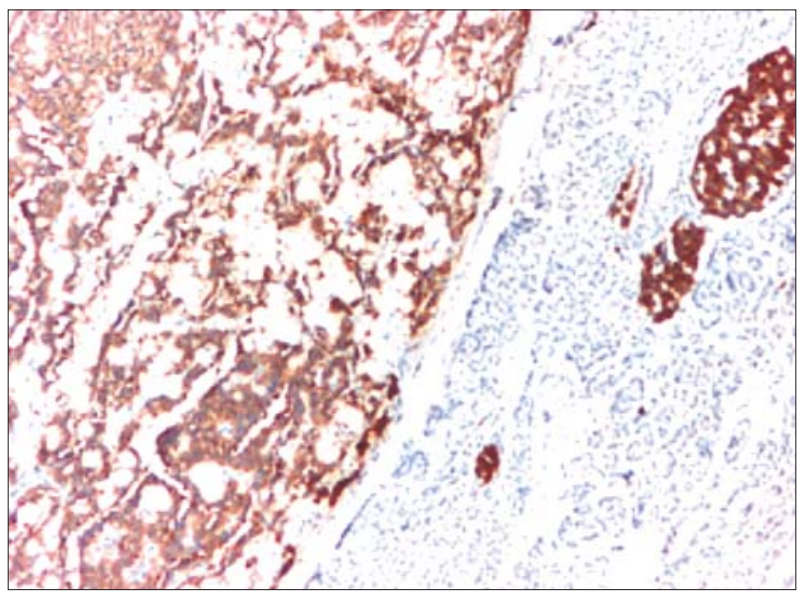

Figure 9. Immunohistochemistry of pancreatic endocrine tumor: intensely positive synaptophisin

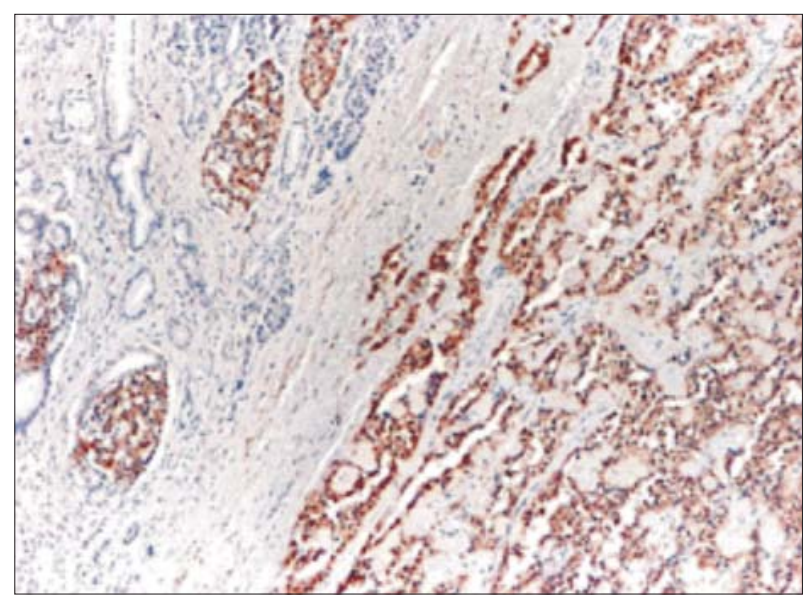

Figure 10. Immunohistochemistry of pancreatic endocrine tumor: intensely positive neuron specific enolase 


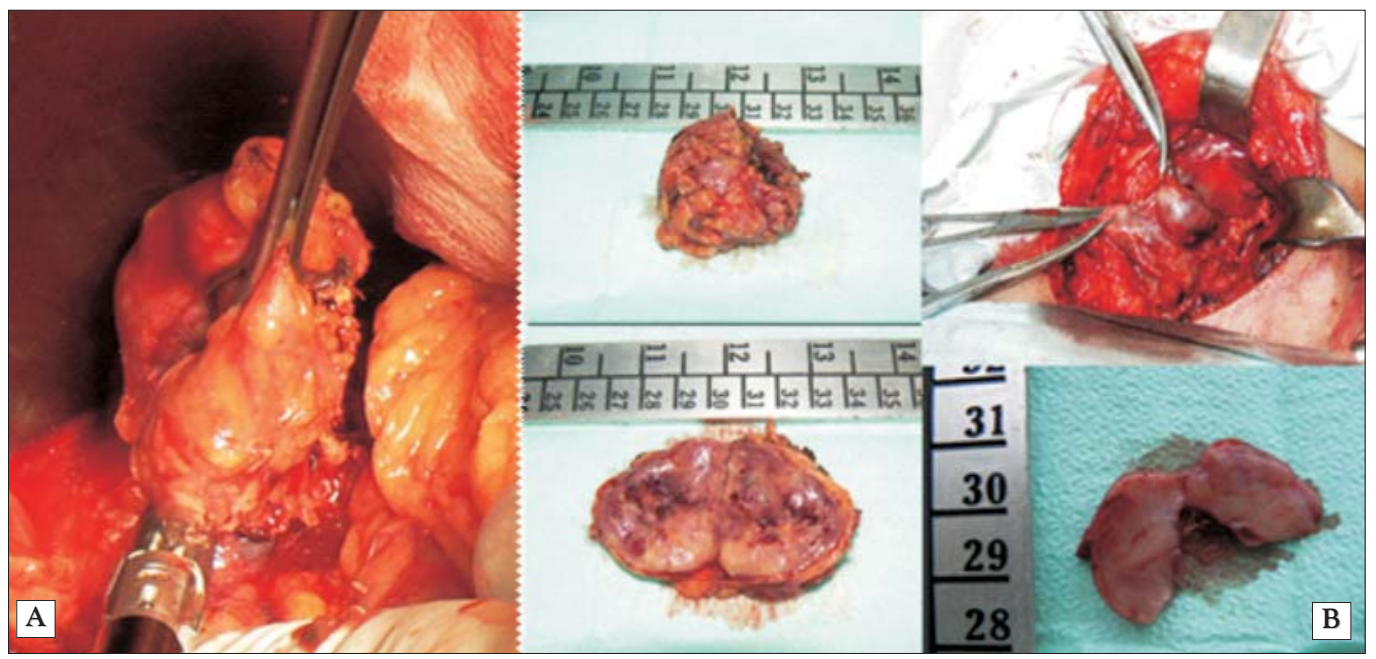

Figure 11. MEN I pancreatic insulinoma (A), parathyroid adenoma (B)

and $57 \%$ for lymph node metastases; Octreoscan $^{\circledast}$ has a sensitivity of $65 \%$ for localized duodenal-pancreatic tumors, $20 \%$ for tumors located on the tail of the pancreas, and $71 \%$ for metastases and the combination of the two techniques increases the sensitivity to 94\% (11). The treatment of ZES has two objectives: control of gastric acid secretion and gastrinoma ablation. The patient diagnosed with ZES syndrome will receive gastric antisecretory treatment (proton pump inhibitors) until imaging investigations can locate the tumor and the tumor is removed. The doses will be adjusted so that the basal acid output to be below $10 \mathrm{mEq} / \mathrm{h}$. In patients who underwent gastric resection the doses should ensure a basal acid output below $5 \mathrm{mEq} / \mathrm{h}$. The already described principles of treatment should be also observed in case of sporadic forms, when pancreatic resections is indicated, and in case of metastases when an aggressive approach is recommended. Careful intraoperative exploration, supplemented by intraoperative ultrasound and perioperative echoendoscopy is mandatory, allowing the identification of the extra-pancreatic synchronous localization (gastric parietal, duodenal, biliary tract).

The first two cases (48- and 62-year-old women, respectively) were admitted in emergency with peptic ulcers complications and different recurrent surgical procedures have been performed. In one case the postoperative course was unfavorable and then fatal due to complications of another peptic ulcers.

In another case, a 41-year-old woman with diffuse PNET located in the pancreatic tail we performed splenopancreatectomy with uneventful postoperative course. A 33-year-old woman was admitted in emergency for peritonitis caused by jejunal peptic ulcer perforation. We performed enterectomy; subsequently, ultrasound revealed a parathyroid adenoma and CT scan a pituitary adenoma (MEN I); angiography detected a possible $1.5 \mathrm{~cm}$ tumor in the pancreatic tail;

Reintervention was necessary (spleenpreserving left pancreatectomy). Postoperative course was unfavorable with upper GI hemorrhage and severe metabolic dysfunction and the patient died.

A 28-year-old man with history of various surgical interventions for recurrent peptic ulcers was admitted with hyperparathyroidism; imaging investigations detected a parathyroid adenoma and pituitary adenoma (MEN I) and possibly a pancreatic tail tumor. Resection of the tumor located in the pancreatic body (Fig. 12) associated with total gastrectomy were performed. Postoperative course was uneventful and the patient is still alive. 


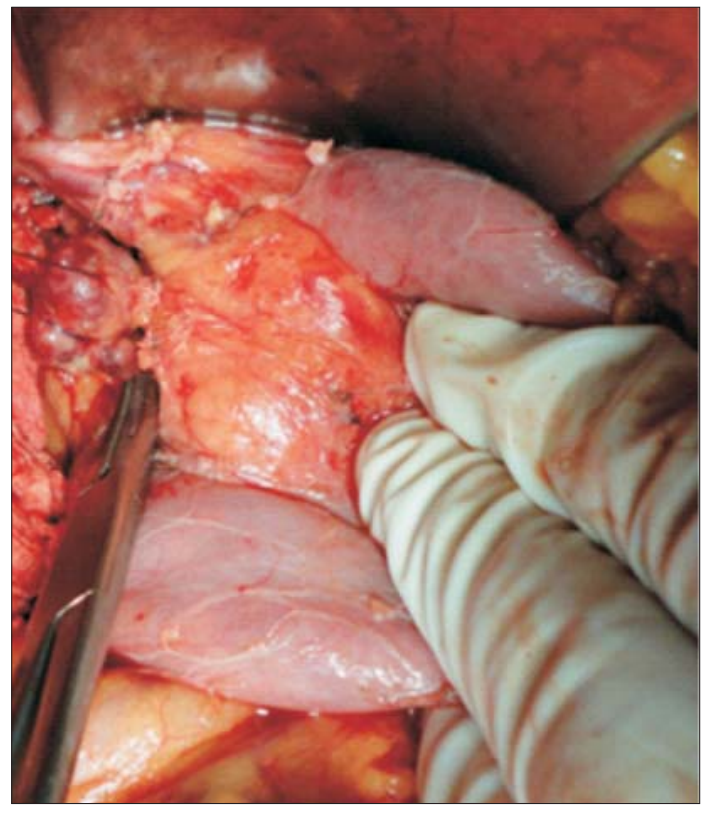

Figure 12. PET, intraoperatory view - gastrinoma

A 57-year-old man with a history of peptic ulcers and surgery for parathyroid adenoma (MEN I) was diagnosed by imaging techniques with tumors of the pancreatic body and tail, lesser curvature of the stomach and duodenum I; high gastrin levels $>1000 \mathrm{pg} / \mathrm{mL}$ ) were recorded. Spleen-preserving subtotal pancreatectomy and resection of gastric and duodenal tumors ( 3 tumors: $2.2 \mathrm{~cm}+0.8 \mathrm{~cm}+$ $1.4 \mathrm{~cm}$ ) were performed. Histopathological examination identified in the pancreas G2 endocrine carcinoma; in the gastric tumor endocrine carcinoma; and in the duodenal tumor - PNET with Ki index 8\%. Postoperative course was uneventful and the patient is still alive.

Another case of treated MEN: a 35-year-old man who underwent gastric resections for operated (totalization of gastrectomy) multiple relapsed gastroduodenojejunal peptic ulcers was admitted with clinical and biological manifestations of hyperparathyroidism. Cervical ultrasound revealed bilateral parathyroid adenomas. Pancreatic tumor enucleation and ablation of the 2 parathyroid adenomas by Koher cervicotomy were performed, the postoperative course being uneventful. Histopathological examination made the diagnosis of parathyroid adenoma, confirmed by immunohistochemistry.

\section{Nonfunctional PNET}

Also operated were 5 patients with nonfunctional PNET - 4 female and 1 male patients. Nonfunctional PNETs are pancreatic tumors with histological features of endocrine tumor but without hormone secretion, can produce polypeptides, but which are not functional and do not cause any symptoms. In our cases nonfunctional PNETs ranking third in frequency of PNETs, after insulinoma and gastrinoma, like in literature (6). Nonfunctional PNETs are large (over $5 \mathrm{~cm}$ ), solitary, over $60 \%$ have cephalic localization, and over $60 \%$ of cases are malignant. In 2 cases the tumors were located in the pancreatic tail (we performed splenopancreatectomy and spleen-preserving left pancreatectomy, respectively) and in the remaining 3 cases the tumors were located in the pancreatic head (pancreaticoduodenectomy and Beger's operation have been performed) (Fig. 13). The prognosis is better than for pancreatic adenocarcinomas, with a 5-year survival for malignant tumors exceeding $50 \%$.

\section{PNET - ACTHoma}

A 27-year-old women was admitted with pain in the right abdominal quadrant, flush, amenorrhea, Cushing syndrome; ultrasound examination revealed multiple hypoechoic tumors of different sizes $(30-45 \mathrm{~mm})$ disseminated in the liver segments VI, VII and III. CT scan also confirmed the number and sites of liver tumors; no other tumors were found; the pancreas was described as "normal". Laparoscopic non-anatomic metastasectomy using LigaSure (for histological exam) - and thermoablation of the other tumors were performed (Fig. 14). Pathological exam revealed metastasis of one malignant endocrine tumor. Immunohisto-chemistry: positive staining for chromogranin, neuron specific enolase, and cytokeratins. After a few weeks, she was admitted to the Gastroenterology Institute for gastrointestinal bleeding. An upper endoscopy 

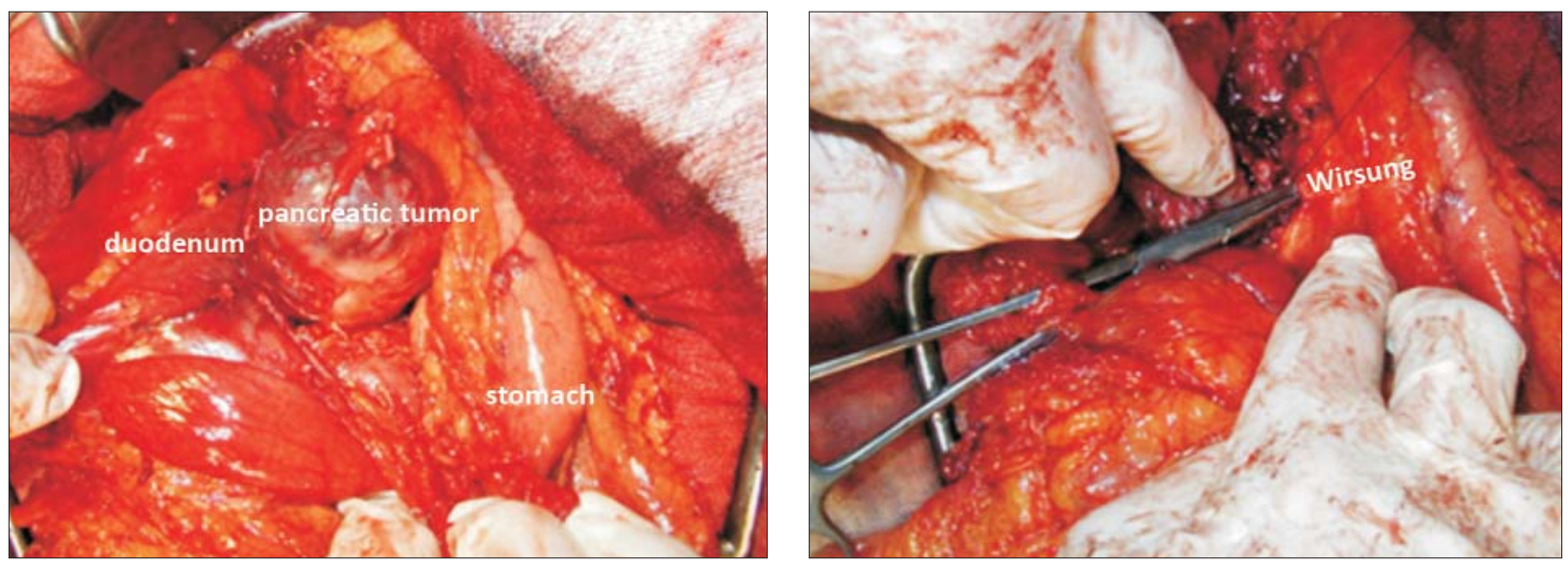

Figure 13. Intraoperatory view: Beger pancreatectomy for PET - nonfunctional tumors

and video capsule endoscopy is used to diagnose multiple duodenal and jejunal hemorrhagic ulcers. Treatment consisted in octreotide, insulin, $\mathrm{H}+$ blockers. The patient was then referred to the Endocrinology Clinic for further testing and were found a high cortisol levels, low potassium levels and high ACTH levels. Treatment with ketoconazole and metyrapone resulted in a decrease in plasma cortisol level. A new CT scan revealed a pancreatic tumor $(3 \mathrm{x}$ $2.5 \times 1 \mathrm{~cm}$ ), located in the pancreatic neck. PET scan revealed enlarged adrenal glands with intense marker uptake, a pancreatic tumor and multiple liver metastasis (Fig. 15). Indium ${ }^{111}$ octreotride scan suggested 5 liver nodules, one pancreatic body nodule, and a right pelvic nodule (Fig. 16). Following a new episode of gastrointestinal hemorrhage, upper endoscopy revealed acute esophagitis, esophageal stenosis and Barrett's esophagus. The patient underwent three more surgeries: bilateral ovariectomy, jejunostomy, and bilateral adrenalectomy for a better control of cortisol secretion. Microscopy revealed a metastasis of endocrine tumor in resected right ovary and hyperplasia of adrenal glands. Immunehistochemistry: intensly positive chromogranin, synaptophysin, Ki 67 $89 \%$. A vertebral metastasis causing paraplegia complicated the course and she died 18 months after first hospital admission.

ACTH-secreting PNETs are very rare, so far less than 100 ACTHomas have been reported in the literature. Ectopic ACTH syndrome (EAS)

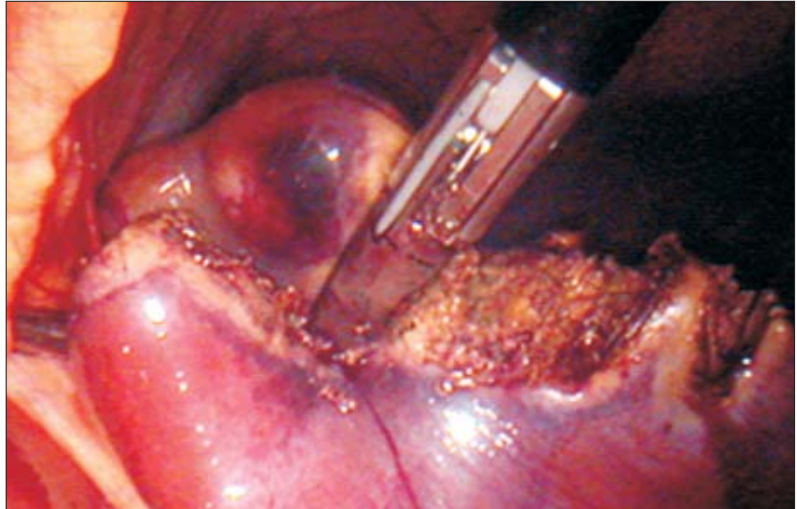

Figure 14. ACTHoma, intraoperatory view: liver metastasis, nonanatomic hepatectomy using LigaSure (for histological exam)

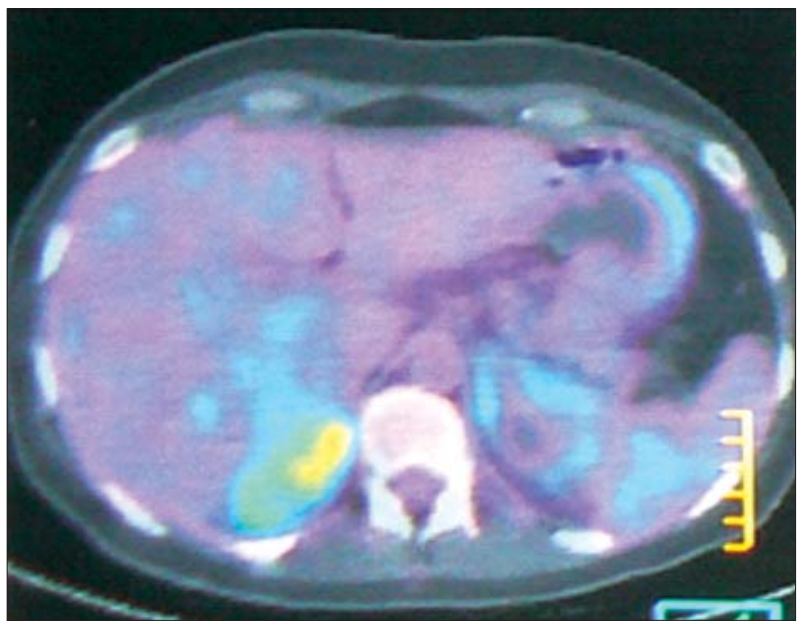

Figure 15. ACTHoma, PET-CT scan: enlarged adrenal glands with intense marker absorption 


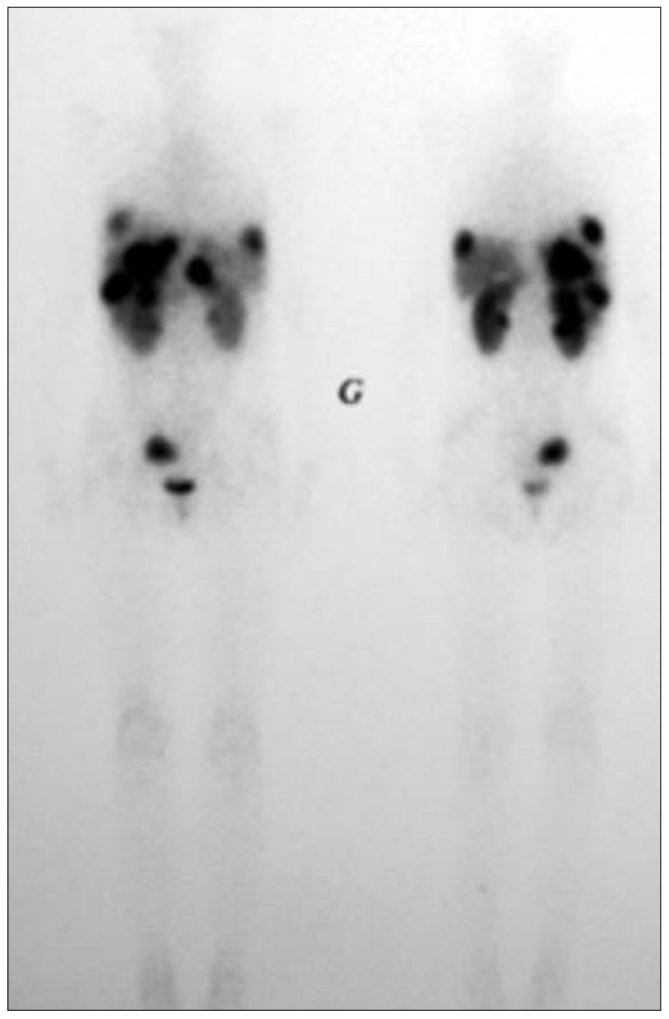

Figure 16. ACTHoma, octeotridescan (Indium ${ }^{111}$ ) multiple liver metastasis, tumor in the body of the pancreas and right ovarian tumor tumors but their incidence is increasing. They have a relatively heterogeneous morphology and their management is always challenging.

Immunohistochemistry - mandatory for: confirmation (most cases were highly/ moderately positive for chromogranin), assessment of proliferation and biological behavior, thus facilitating the use of specific therapy Sandostatin.

For all PNETs, it is necessary to recognize the clinical signs of secreting tumors and to plan the laboratory investigations.

In insulinomas, less aggressive pancreatic resection is preferred to tumor resection, which has a higher postoperative morbidity rate. Gastrinomas and ACTHomas are aggressive tumors with a poor prognosis.

Tumor resection, absence of liver and lymph node metastases, and the presence of MEN 1 syndrome are associated with a better survival rate.

\section{Conflict of Interest}

The authors declare no conflicts of interests.

\section{References}

occurs in about $5-10 \%$ of all patients with ACTH-dependent hypercortisolism (14). Most ACTHomas are malignant, at the time of diagnosis $80-90 \%$ being metastatic. Clinically they are characterized by the occurrence of a severe Cushing's syndrome: central obesity, hirsutism, telangiectasia, stretch marks, and hyperhidrosis. Metastases, who are present at the time of diagnosis, are most commonly hepatic, but quite frequently they are also detected in the ovary, fact confirmed by our case and aggressive surgical cytoreduction, with resection/ destruction of primary tumor and hepatic and extrahepatic metastases is the only option to control the symptoms. Adrenalectomy is also indicated to control cortisolemia (15). As to the drug treatment, ketoconazole and somatostatin analogues appear to be effective in controlling hypercortisolemia (16).

\section{Conclusions}

Pancreatic endocrine tumors (PET) are rare
1. Ardill JES. Circulating markers for endocrine tumors of gastroenteropancreatic tract. Ann Clinical Biochem. 2008;45:539-559.

2. Rindi G, Petrone G, Inzani F. The 2010 WHO classification of digestive neuroendocrine neoplasms: a critical appraisal four years after its introduction. Endocr Pathol. 2014;25:186-192.

3. Turaga KK, Kvols LK. Recent progress in the understanding, diagnosis, and treatment of gastroenteropancreatic neuroendocrine tumors. CA Cancer J Clin 2011; 61: 113-132.

4. Tomulescu V, Popescu I. Diagnosis and surgical management in gastrointestinal neuroendocrine tumors. Chirurgia 2011; 106(2): 151-61.

5. Ansari A, Meeran K, Bloom SR. Classification of neuroendocrine tumors. In Hay ID, Wass JAH, editors, Clinical Endocrine Oncology, 2nd Edition, Massachusetts, Oxford: Blackwell Publishing; 2008. p. 437-442.

6. Jensen R. Pancreatic Endocrine tumors. In, Hawkey C, Bosch J, Garcia-Tsao G, Chan FL, editors, Texbook of clinical gastroenterology and hepatology - 2nd ed. Oxford: Wiley-Blackwell; 2012. p. 844-858

7. Juvara I, Dragomirescu C, Gavrilescu S, Vereanu I. Organic hypoglycemia of pancreatic origin (50 surgical cases).Rev Chirurgia.(Bucur)1983;32(4):269-78.

8. Pătrașcu T, Doran H, Belușică L, Prunaiche M, Goanță A, Vereanu I. Organic hypoglycemia of pancreatic cause. Chirurgia (Bucur). 2003: 98(6):509-14

9. Vanderveen K, Grant C. Insulinoma. In: Sturgeon C (Ed). Endocrine Neoplasia, Cancer Treatment, and Research. Vol 153. New York, USA: Springer Science and Media, LLC, 2010, Chapter 13. p. 210-252.

10. Kaplan E L, Wayne J D, Nagar S, Grogan RH. Insulinomas (Endocrine Pancreas) Ch. 98, in Textbook of Endocrine Surgery. 
Third Edition. Clarck O, Duh Q-Y, Kebebew E., Gosnell J, Shen W. The Health Sciences Publisher Philadelphia. 2016, p. 1177 - 1199.

11. Mirallie E, Pattou F, Malvaux P, Filoche B, Gochaux JM. Value of endoscopic ultrasonography and somatostatin receptor scintigraphy in the preoperative localization of insulinomas and gastrinomas. Experience of 54 cases, Gastroenterol Clin Biol 2002; 26(4): 360-366.

12. Kulke MH, Bendell J, Kvols L, Picus J, Pommier R, Yao J. Evolving diagnostic and treatment strategies for pancreatic neuroendocrine tumors. Journal of Hematology \& Oncology. 2011;4:29.

13. Zollinger R, Ellison E. Primary peptic ulceration of the jejunum associated with islet cell tumors of the pancreas. Ann Surg. 1955; 142: $709-713$.
14. Moldovanu R, Vasilescu A, Târcoveanu E, Lupaşcu C, Mehier H, Crumpei $\mathrm{F}$ et al. Late diagnosis of an end stage pancreatic acth-oma; case report and literature review. Jurnalul de chirurgie. 2008:4(3):217-24

15. Doherty GM, Jayarajan S. Rare functioning pancreatic endocrine tumors, In, Hubbard J, Inabnet WB, Lo CY, editors, Endocrine surgery: principles and practice. London: Springer Verlag; 2009. p. 523-532.

16. Salgado LR, Fragoso MC, Knoepfelmacher M, Machado MC, Domenice S, Pereira MA, de Mendonça BB. Ectopic ACTH syndrome: our experience with 25 cases. Eur J Endocrinol. 2006; 155(5):725-33. 